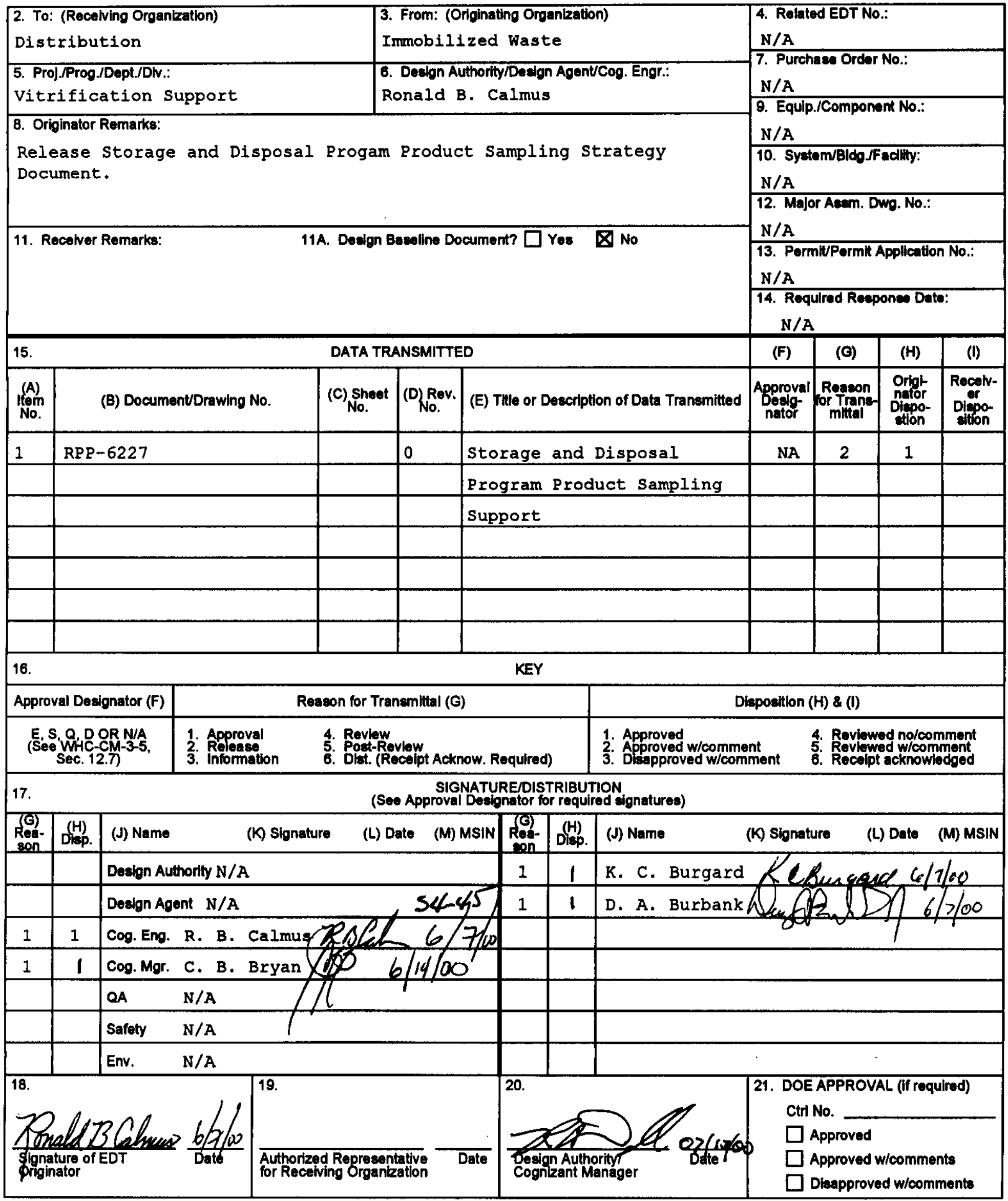




\title{
Release Storage and Disposal Program Product Sampling Support
}

\author{
Ronald B. Calmus \\ CH2M Hill Hanford Group, Inc. \\ Richland, WA 99352 \\ U.S. Department of Energy Contract DE-AC06-99RL14047 \\ $\begin{array}{ll}\text { EDT/ECN: } 624999 & \text { UC: } \\ \text { Cost Center: } 7 \mathrm{C} 800 & \text { Charge Code: } 109945 \\ \text { B\&R Code: } & \text { Total Pages: } 22\end{array}$
}

Key Words: Sample strategy, Immobilized High-Level Waste, storage and Disposal

Abstract: This document includes recommended capabilities and/or services to support transport, analysis, and disposition of Immobilized HighLevel and Low-Activity Waste samples as requested by the US DOE - Office of River Protection (DOE-ORP) as specified in the Privatization Contract between DOE-ORP and BNEL Inc. In addition, an approved implementation path forward is presented which includes use of existing Hanford site services to provide the required support capabilities.

TRADEMARK DISCLAIMER. Reference herein to any epecific commercial product, procese, or service by trade name, trademark, manufacturer, or otherwiee, does not necesearlly conettute or imply te endoreement, recommendation, or favoring by the United States Government or any agency thereof or its contractore or subcontractors.

Printed in the United States of America. To obtain copies of this document, contact: Document Control Services, P.O. Box 950, Mallatop H6-08, Richland WA 99352, Phone (509) 372-2420; Fax (509) 376-4989.
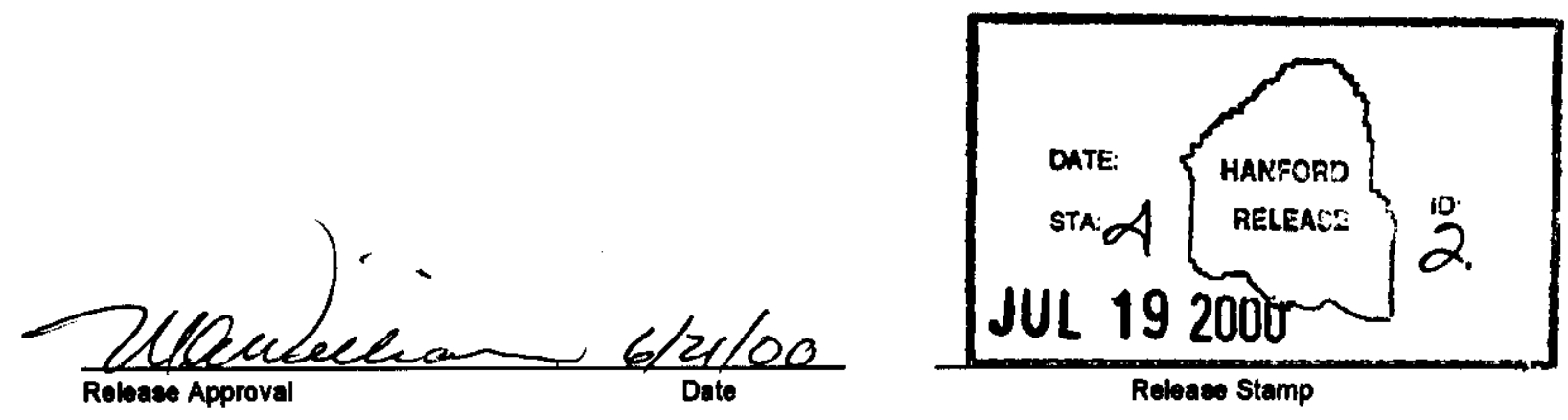

\section{Approved For Public Release}


RPP-6227

Revision 0

\section{EXECUTIVE SUMMARY}

The U.S. Department of Energy (DOE) has the right to request representative product samples from the Privatization Contractor providing waste immobilization services. Therefore, the River Protection Project, Storage and Disposal Program must provide the capabilities to support the transportation and analysis of these samples. This document identifies an approach for supplying the services necessary to receive, transport, and analyze both immobilized high-level waste (IHLW) and immobilized low-activity waste (ILAW) product samples that are requested by the DOE.

The frequency upon which the DOE may request a product sample is the most important parameter that influences the scope of services that must be provided. The fundamental premise that guided subsequent study development was that a product sample request is part of a general quality assurance oversight function by the DOE and it is only one of several techniques, such as onsite inspection and production record audits, that may be used to address the oversight function. Based on this premise, 2 IHLW samples per year and $12 \mathrm{ILAW}$ samples per year were adopted as reasonable values for the frequency of DOE product sample requests.

For both IHLW and ILAW, existing Hanford Site services (sample transportation and analytical capabilities) were determined to be sufficient to support the expected annual number of DOE product sample requests. In addition, the recommended strategy to procure a bundled transportation service (i.e., an onsite contractor provides the sample package and sample transportation) renders capital expenditures unnecessary. Therefore, during Phase 1 the annual funding needed for IHLW sample requests and for ILAW sample requests is estimated at $\$ 90,000$ and $\$ 288,000$, respectively.

The flexibility also exists to transport samples to an offsite laboratory via commercial carrier because appropriate sample packages, approved by the U.S. Department of Transportation, were identified for both IHLW and ILAW. The ability to ship offsite provides contingency should the number of samples temporarily surge for some unforeseen reason. In addition, a potentially larger number of laboratories could competitively bid on a procurement for analytical services, thereby allowing the DOE to realize the lowest cost. The transportation cost would, however, increase for an offsite shipment.

Given the ready availability of all services needed to support a DOE sample request (e.g., sample package, transportation mechanism, analytical laboratory, etc.), initiation of FY 2000 activities to prepare a functions and requirements document and an alternatives generation and analysis and associated decision process for this activity is not recommended. Furthermore, these services can be obtained through relatively simple procurements that do not require long lead times. Therefore, the only near-term action necessary is to ensure that the multi-year work plan identifies the various procurements and funding needed to implement this approach. 


\section{RPP-6227}

Revision 0

\section{CONTENTS}

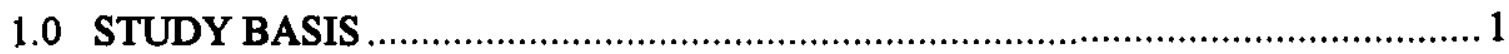

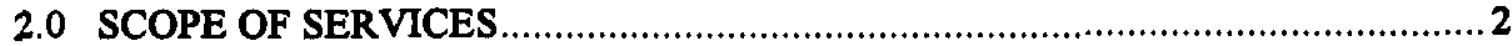

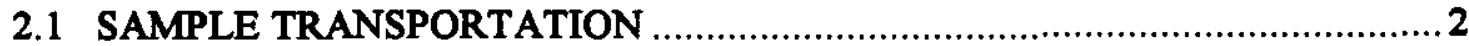

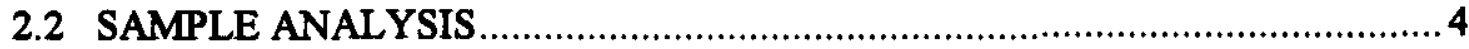

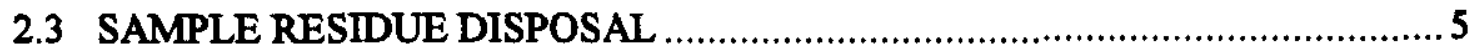

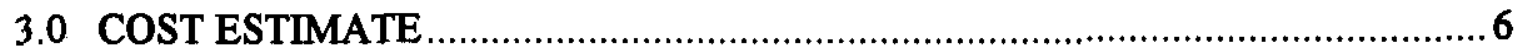

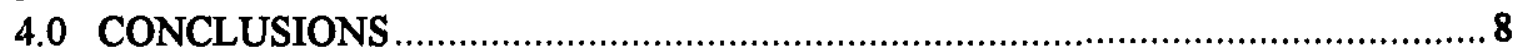

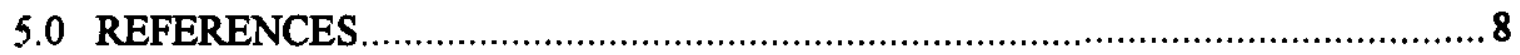

\section{APPENDICES:}

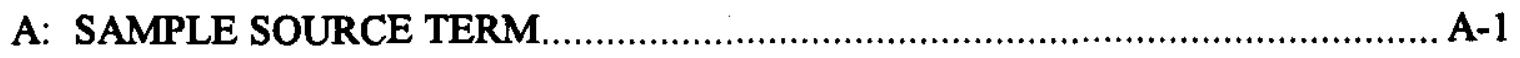

B: SAMPLE TRANSPORTATION PACKAGES .......................................... B-1

\section{LIST OF TABLES}

Table 2-1. Radionuclide/Chemical Fingerprint Analytes........................................ 5

Table 3-1. Packaging, Transportation, and Analysis Cost Summary. .......................... 7

Table 3-2. Bundled-Service Cost Summary. ...................................................... 7 
RPP-6227

Revision 0

\section{STORAGE AND DISPOSAL PROGRAM PRODUCT SAMPLING SUPPORT}

The Privatization Contract (DOE 1996) Section E, Inspection and Acceptance, states:

DOE reserves the right at any time to: 1) verify Contractor submitted documentation, and 2) verify product compliance with Contract requirements. Verification methods used by DOE include, but are not limited to, independent inspection, review of operating records, or independent sampling and analysis of product. Upon request by DOE, the Contractor shall provide representative product samples.

Given that the U.S. Department of Energy (DOE) could request a product sample in accordance with the Section E clause, the River Protection Project, Storage and Disposal Program must provide the capabilities to support the DOE product sample requests. This document's purpose is to establish an approach for supplying the services necessary to receive, transport, and analyze both immobilized high-level waste (IHLW) and immobilized low-activity waste (ILAW) product samples that could be requested by the DOE.

\subsection{STUDY BASIS}

The frequency upon which the DOE may request a product sample is the most important parameter that influences the scope of services necessary to support that must be provided. Additional parameters of interest include the required sample size, which is a function of the analyses to be performed on the sample, required analytical turnaround time, and final disposition of samples (i.e., disposal versus archival). Definitive values for these parameters are not available because both the Privatization Contractor's product qualification/process control approach and the DOE's product acceptance process are under development. Therefore, enabling assumptions relative to these parameters are required to proceed.

The Section E clause wording clearly implies that a product sample request is part of a general quality assurance oversight function by the DOE and it is only one of several techniques, such as onsite inspection and production record audits, that may be used to address the oversight function. Based on this fundamental premise, the following enabling assumptions were formulated and adopted (Burbank 2000).

- Capabilities to support a DOE product sample request must be available concurrent with initiation of IHLW and ILAW production and must span the entire Phase 1 production period.

- The Privatization Contractor will provide all features necessary to collect an appropriate product sample (either ILAW or IHLW), emplace the sample in a 
RPP-6227

Revision 0

DOE-supplied transportation package, and load the package into a DOE-provided transportation system.

- The maximum (not to exceed) product sampling frequency is one event every six months for IHLW and one event every month for ILAW.

- The maximum product sample size is $40 \mathrm{~g}$ of glass per event for IHLW and $100 \mathrm{~g}$ of glass per event for ILAW.

- Product sample analyses are limited to chemical composition, radionuclide composition, and a glass durability test. A glass durability test encompasses a Product Consistency Test (PCT) for IHLW and a PCT, Toxicity Characteristic Leaching Procedure (TCLP) test, or Vapor Hydration Test (VHT) for ILAW.

- The required turnaround time for analyses (i.e., elapsed period between sample delivery to the laboratory and issuance of the analytical report) is not to exceed 45 days.

- Product samples will not be archived and analytical residues, including any unused sample portions, will be disposed of as incidental waste in near-surface disposal at the Hanford Site.

These enabling assumptions establish the basis for development of the scope of services necessary to fully support IHLW and ILAW product sample requests by the DOE.

\subsection{SCOPE OF SERVICES}

The following defines the scope of services necessary to support a sampling program bounded by the parameters defined in Section 1.0.

\subsection{SAMPLE TRANSPORTATION}

A wide range of transportation packages are potentially available for use at the Hanford Site (McCarthy 1996). The two most important factors in selecting an appropriate transportation package are the payload's curie content and dose rate. Also notable is whether the sample is intended to be shipped offsite or onsite over publicly accessible roads. Transportation over publicly accessible roads requires use of a package approved by the U.S. Department of Transportation (DOT). Only a small subset of common Hanford Site transportation packages are DOT-approved. The most conservative approach is to presume that the offsite shipment option must be retained for product sample requests. Use of a DOT-approved package also allows shipment via a commercial carrier. 
RPP-6227

Revision 0

For the ILAW product sample quantity involved ( $100 \mathrm{~g}$, maximum), the associated activity is much less than the maximum activity of radioactive material permitted in a DOT Type A package (as defined in 49 CFR 173 Subpart I). Appendix A provides an estimated payload (sample) activity and the associated Type A activity limits. In addition, the surface dose rate from a package containing this quantity of ILAW $(\sim 3.4-\mathrm{cm}$ cube) would be less than $200 \mathrm{mrem} / \mathrm{hr}$, given that an approximately 1.5 -m cube of ILAW has an external dose rate (at contact) of less than $1,000 \mathrm{mrem} / \mathrm{hr}$. Therefore, a standard Hanford Site Hedgehog is an acceptable package for containing the ILAW sample during transportation. Appendix B provides a description of the Hedgehog.

An IHLW product sample quantity of $40 \mathrm{~g}$ could potentially exceed the Type A package activity limit if the ${ }^{241} \mathrm{Am}$ content is at or near its maximum (see Appendix A). This scenario is not, however, considered very likely because the System Operation and Utilization Plan (SOUP) projects that the ${ }^{241} \mathrm{Am}$ content in IHLW should be an order of magnitude lower than the hypothetical maximum (Kirkbride 1999). Even if the ${ }^{241} \mathrm{Am}$ content were at the maximum, a Hedgehog could still be used. The product sample would simply need to be subdivided into several separate packages (possibly up to five Hedgehogs).

A Hedgehog appropriately sized for the IHLW sample (30-ml pig configuration) provides about $3.8 \mathrm{~cm}$ of stainless steel shielding. This shielding would be insufficient to reduce the dose rate at the Hedgehog's external surface to less than $200 \mathrm{mrem} / \mathrm{hr}$ if the IHLW sample represents glass with a ${ }^{137} \mathrm{Cs}$ content greater than about $10 \%$ of the maximum allowed limit. Again, a high- ${ }^{137} \mathrm{Cs}$ IHLW sample could be subdivided into several Hedgehogs. Alternately, a Post-Accident Sample-1 (PAS-1) cask could be used.

The PAS-1 cask was developed to carry "post-accident" samples from commercial nuclear reactors (Smith 1995). The PAS-1 cask provides ample shielding for a $40 \mathrm{~g}$ IHLW sample and it is also licensed for Type B quantities of radioactive material which are well in excess of those predicted for the maximum IHLW product sample. The PAS-1 cask has been used at the Hanford Site to transport 4-L samples of Tank Farm waste. Additional details of the PAS-1 cask are presented in Appendix B.

A standard government vehicle (e.g., flatbed truck) can be used for transporting either the Hedgehog or the PAS-1 cask to an onsite laboratory. Given that the Hedgehog and the PAS-1 cask are DOT-approved packages, product samples could be transported beyond the Wye Barricade to the 325 Building Laboratory, for example, without disrupting normal Hanford Site operations (i.e., temporary closure of public access roads). Furthermore, product samples could be shipped to an offsite laboratory via a commercial carrier should it ever be necessary.

A minor concern with the Hedgehog is that an integral component has a limited life of approximately eight uses and is no longer manufactured. This component is the SafeSend ${ }^{1}$ plastic bottle that holds the sample pig. Therefore, either an extended life

\footnotetext{
${ }^{1}$ SafeSend is a registered trademark of $3 \mathrm{M}$ Corporation.
} 
RPP-6227

Revision 0

must be approved or a substitute developed. Given that the Hedgehog has a long-term and extensive mission at the Hanford Site beyond the Storage and Disposal Program needs (e.g., tank characterization), this concern should be resolved before Hedgehogs are required to support product sampling.

\subsection{SAMPLE ANALYSIS}

Based on the estimated sampling event frequency and required analytical turnaround time, both the 222-S Laboratory and 325 Building Laboratory are viable candidates for performing the necessary analyses. Both laboratories are expected to have relatively stable missions for the foreseeable future. For the case of the ILAW sample, the low dose rate renders sample analysis via an offsite commercial laboratory an extremely viable option.

Analytical turnaround times are not expected to impose any appreciable constraint on the onsite laboratories. Typical analytical turnaround times at the 325 Building Laboratory are on the order of three weeks for ILAW samples and four weeks for IHLW. If high priority were placed on the analyses, turnaround times could be reduced to approximately one week. The high-priority designation (authorized overtime) would, however, increase analytical costs 1.5 to 2 times beyond those normally charged.

The quantity of glass (either IHLW or ILAW) needed for radionuclide/chemical analyses is on the order of a few grams. A PCT requires at least 3 to $5 \mathrm{~g}$, with $20 \mathrm{~g}$ of prepared sample being preferable. However, a sample size sufficient for a PCT inherently provides enough material for radionuclide/chemical analyses. Sample preparation for a PCT entails a crushing/sifting operation. This operation yields an ample quantity of glass fines (upwards of $50 \%$ of the original sample quantity) which are available for radionuclide/chemical analyses.

As an alternative to a PCT, a ILAW sample could be subjected to a TCLP test or a VHT. A TCLP test is similar to a PCT, in so far as both measure glass durability, but the former is sanctioned by the U.S. Environmental Protection Agency. The recommended sample size for a TCLP test is $100 \mathrm{~g}$ of material plus an additional $100 \mathrm{~g}$ for a duplicate (EPA 1996). However, a sample size on the order of 25 to $30 \mathrm{~g}$ could probably be defended. Even if the larger sample quantity were needed, it would not be an important factor in selecting transportation and analytical support capabilities for the product sample because the dose rate from small quantities of $I \mathrm{AW}$ is not a controlling parameter.

A VHT is also a measure of glass durability. In this test monolithic glass specimens are exposed to water vapor at elevated temperatures to accelerate the progression of glass corrosion and the formation of alteration products (PNNL 2000). An ILAW sample size of approximately $1 \mathrm{~g}$ is required for a VHT.

Although standard analytical techniques may yield more information, the required scope of radionuclide/chemical analyses could be limited to that necessary to "fingerprint" the 
product sample (i.e., provide enough information to confirm that the Privatization Contractor's reported composition is reasonable, yet avoid costly analytical procedures to quantify trace components). Examples of analytes that may be included in a fingerprint analysis for both IHLW and ILAW are presented in Table 2-1. These analytes represent components that are potentially present in appreciable quantities and are either contractually restricted or reflect important glass properties (dose rate, decay heat, durability, disposal system performance, etc.). The purpose of this analyte list is to establish an approximate scope for analytical services that are priced later in the report The exact analytes specified for any given product sample collected during actual production are expected to be selected on a case-by-case basis.

Table 2-1. Radionuclide/Chemical Fingerprint Analytes.

\begin{tabular}{|c|c|c|c|c|}
\hline \multicolumn{3}{|c|}{ Elements } & \multicolumn{2}{|c|}{ Radionuclides } \\
\hline \multicolumn{5}{|c|}{ Immobilized High-Level Waste (IHLW) } \\
\hline Ag & $\mathbf{K}$ & $\mathbf{R h}$ & ${ }^{60} \mathrm{Co}$ & ${ }^{154} \mathrm{Eu}$ \\
\hline$\overline{A l}$ & $\overline{\mathrm{Li}}$ & $\mathbf{R u}$ & ${ }^{90} \mathrm{Sr}$ & ${ }^{155} \mathrm{Eu}$ \\
\hline $\mathbf{B a}$ & $\overline{\mathrm{Mg}}$ & $\mathbf{S}$ & ${ }^{125} \mathrm{Sb}$ & ${ }^{241} \mathrm{Am}$ \\
\hline$\overline{\mathrm{Bi}}$ & $\mathrm{Na}$ & $\mathbf{S i}$ & ${ }^{137} \mathrm{Cs}$ & \\
\hline $\mathrm{Ca}$ & $\mathrm{Ni}$ & $\mathrm{Ti}$ & & \\
\hline $\mathrm{Cd}$ & $\mathbf{P}$ & $\mathbf{U}$ & & \\
\hline $\mathrm{Cr}$ & $\mathrm{Pb}$ & $\mathbf{Z r}$ & & \\
\hline $\mathrm{Fe}$ & $\mathbf{P d}$ & & & \\
\hline \multicolumn{5}{|c|}{ Immobilized Low-Activity Waste (ILAW) } \\
\hline $\mathrm{Al}$ & F & $\mathrm{Na}$ & ${ }^{60} \mathrm{Co}$ & ${ }^{154} \mathrm{Eu}$ \\
\hline B & $\mathrm{Fe}$ & $\mathbf{P}$ & ${ }^{90} \mathrm{Sr}$ & ${ }^{155} \mathrm{Eu}$ \\
\hline $\mathrm{Ca}$ & $\mathbf{K}$ & $\mathbf{S}$ & ${ }^{99} \mathrm{Tc}$ & ${ }^{237} \mathrm{~Np}$ \\
\hline \multirow[t]{2}{*}{$\mathrm{Cl}$} & $\mathbf{L i}$ & $\mathbf{S i}$ & ${ }^{126} \mathrm{Sn}$ & ${ }^{241} \mathrm{Pu}$ \\
\hline & & & ${ }^{137} \mathrm{Cs}$ & ${ }^{241} \mathrm{Am}$ \\
\hline
\end{tabular}

\subsection{SAMPLE RESIDUE DISPOSAL}

The waste residue from ILAW product sample analyses and any unused portion of ILAW product samples, all being low-level mixed waste, can be disposed in the Hanford Site burial grounds provided it is packaged to meet the appropriate acceptance requirements (FDH 1998). For the IFLW, product sample test residues (including unused sample portions) are considered low-level waste or transuranic waste provided the following conditions are satisfied (Bilson 1999).

- The waste residue is from laboratory or pilot-scale testing. 
RPP-6227

Revision 0

- The waste residue from each individual high-level waste sample event is less than $100 \mathrm{Ci}$ and the yearly total waste from high-level waste analyses for all Hanford Site laboratory operations is less than $1,000 \mathrm{Ci}$.

- The waste residue, as packaged for disposal, complies with the Hanford Site burial grounds acceptance criteria (FDH 1998).

Assuming the upper bound radionuclide content as presented in Appendix A, a single IHLW sample event will only involve approximately $12 \mathrm{Ci}$ of material. Given a presumption of two IHLW sample events per year, the yearly-total disposal limit would not constrain IHLW sample requests. Also, unused sample portions requiring disposal should not be a frequent occurrence. Prudence would dictate that product sample requests not entail quantities larger than that actually needed for the planned analyses.

\subsection{COST ESTIMATE}

Two Hedgehogs are sufficient to accommodate the potential ILAW sample requests. Although these Hedgehogs could in many instances be used for IHLW samples, the requested IHLW quantity and its associated activity could occasionally necessitate use of a PAS-1 cask. Because the Hedgehog and PAS-1 cask are designed and qualified packages, acquisition cost is limited to procurement.

The capital expenditure needed to support the DOE's product sample request is relatively modest. Previously procured Hedgehogs have been in the range of $\$ 1,500$ each. The approximate procurement cost of a PAS-1 cask is $\$ 250,000$.

The transportation service is estimated to cost about $\$ 400$ per event for a Hedgehog and $\$ 3,000$ per event for a PAS-1 cask. This service encompasses delivery of an empty sample package to the production facility, transportation of a loaded sample package from the production facility to an onsite laboratory, and retrieval of the empty package from the laboratory. Not included in the cost are labor at the production facility to load the transportation package and labor at the laboratory to unload the transportation package. Transportation to on offsite laboratory (e.g., Savannah River) could increase the cost to $\$ 500$ and $\$ 10,000$ for a Hedgehog and PAS-1 cask, respectively.

For the limited radionuclide/chemical analyses necessary for fingerprinting a product sample, the cost is estimated to be between $\$ 10,000$ and $\$ 15,000$ for either IHLW or ILAW. The PCT is expected to cost about $\$ 6,000$ for ILAW and $\$ 10,000$ for IHLW. A TCLP test or VHT on ILAW would cost about $\$ 8,000$. These costs assume the required detection limits and analytical accuracy are similar to those historically specified for glass analyses at the Hanford Site.

The aforementioned cost estimates are summarized in Table 3-1. Based on this information, the initial capital expenditure necessary to support DOE sample requests is minor (i.e., procurement of two Hedgehogs at $\$ 3,000$ and one PAS-1 cask at $\$ 250,000$ ). 
Annual operating expenditures for transportation and analyses could range from $\$ 56,000$ (onsite) to $\$ 110,000$ (offsite) for IHLW samples and $\$ 280,000$ (onsite) to $\$ 295,000$ (offsite) for ILAW samples. The cost estimates for ILAW samples presumes that only one of the three possible durability test (PCT, TCLP, or VHT) will be performed during a single sampling event.

Table 3-1. Packaging, Transportation, and Analysis Cost Summary.

\begin{tabular}{|l|c|c|c|c|}
\hline Item & Hedgehog & PAS-1 & ILAW & IHLW \\
\hline Sample package & $\$ 3,000$ & $\$ 250,000$ & & \\
\hline Transportation Service & $\$ 400$ & $\$ 3,000$ & & \\
\hline Onsite & $\$ 500$ & $\$ 10,000$ & & \\
\hline Offsite & & & $\$ 15,000$ & $\$ 15,000$ \\
\hline Analytical Service & & & $\$ 8,000$ & $\$ 10,000$ \\
\hline Radionuclide/chemical & & & & \\
\hline Durability &
\end{tabular}

An alternate approach that avoids direct procurement of dedicated sample transportation packages is the procurement of sample transportation and packaging as a bundled service (i.e., the contractor provides transportation and furnishes the sample package). The bundled-service cost for a Hedgehog is estimated to be about $\$ 1,000$ per event for transportation to an onsite laboratory and \$1,500 per event for transportation to an offsite laboratory. Use of a PAS- 1 cask would increase the onsite cost to $\$ 20,000$ and offsite cost to $\$ 30,000$. The PAS-1 cask cost estimates presume that the cask is leased by the contractor, rather than a direct procurement. Bundled service costs are summarized in Table 3-2.

Table 3-2. Bundled-Service Cost Summary.

\begin{tabular}{|l|c|c|c|c|}
\hline Item & Hedgehog & PAS-1 & ILAW & IHLW \\
\hline Packaging and Transportation Service & $\$ 1,000$ & $\$ 20,000$ & & \\
\hline Onsite & $\$ 1,500$ & $\$ 30,000$ & & \\
\hline Offsite & & & $\$ 15,000$ & $\$ 15,000$ \\
\hline Analytical Service & & & $\$ 8,000$ & $\$ 10,000$ \\
\hline Radionuclide/chemical & & &
\end{tabular}

Given the relatively low sampling frequency ( 2 events per year for IHLW and 12 events per year for ILAW), procurement of a bundled service from an onsite contractor is an attractive option. This approach eliminates the initial capital expenditure by the Storage and Disposal Program for sample transportation packages. Furthermore, site-wide capital expenditures are minimized because transportation packages can be pooled amongst Hanford Site programs. 
RPP-6227

Revision 0

For IHLW the benefits of a bundled service are even more pronounced. The rental cost of a PAS-1 cask is on the order of $\$ 17,000$ to $\$ 20,000$ per sample event, or about $\$ 40,000$ annually. This is roughly equal to the $\$ 250,000$ initial procurement cost for a PAS-1 cask amortized over an 8 to $10 \mathrm{yr}$ period (assuming a $7 \%$ discount rate). Therefore, direct procurement of a PAS-1 cask would most likely not be cost effective.

\subsection{CONCLUSIONS}

Based on the expected annual number of DOE product sample requests for both IHLW and ILAW, existing Hanford Site services (sample transportation and analytical capabilities) are sufficient to support this activity. In addition, the recommended strategy to procure a bundled service (i.e., an onsite contractor provides the sample package and sample transportation) renders capital expenditures unnecessary. The annual funding needed for $2 \mathrm{IHLW}$ sample requests and for $12 \mathrm{ILAW}$ sample requests is estimated at $\$ 90,000$ and $\$ 288,000$, respectively.

For baseline planning purposes, the recommended approach for analytical services is procurement from an onsite contractor (e.g., 325 Building Laboratory operator). For IHLW samples this is the most reasonable approach given the small number of samples envisioned for Phase 1. The flexibility exists to transport samples to an offsite laboratory via commercial carrier because appropriate DOT-approved sample packages were identified for both IHLW and ILAW. The offsite shipment capability provides contingency should the number of samples temporarily surge for some reason, such as the detection of a major quality deficiency. In addition, a larger number of laboratories could potentially bid on a procurement for analytical services. The transportation cost would, however, increase for an offsite shipment.

Given the ready availability of all features needed to support a DOE sample request (e.g., sample package, transportation mechanism, analytical laboratory, etc.), initiation of two major FY 2000 Multi-Year Work Plan (MYWP) activities are not warranted. These activities are preparation of an IHLW/LAW sample support functions and requirements document, and an alternative generation and analysis, including the associated decision process. Furthermore, the sample request support services can be obtained by relatively simple procurements that do not require long lead times. Therefore, required near-term actions are to close the unnecessary FY 2000 activities, and to ensure that the FY 2001 MYWP identifies the various procurements and funding needed to implement the recommended approach.

\section{S.0 REFERENCES}

49 CFR 173 Subpart I, 1998, "Class 7 (Radioactive) Materials," Code of Federal Regulations, as amended. 
RPP-6227

Revision 0

Bilson, H. E., 1999, Contract No. DE-AC06-96RL13200- Classification of Residual Wastes, Memorandum 99-WPD-037 (H. E. Bilson, Director, Waste Programs Division to R. D. Hanson, President, Fluor Daniel Hanford Inc.), U.S. Department of Energy, Richland Operations Office, Richland, Washington.

Burbank, D. A., 2000, Contract Number DE-AC06-99RL14047; Partial Completion of Fiscal Year 2000 Performance Incentive ORP9.1.1, Section 3, Standard 3 and Section 4, Expectation 3, Letter CHG-0000407 R1 (R. F. Wood, Manager, Contracts Administration to J. J. Short, Contracting Officer, Office of Procurement Services, U.S. Department of Energy, Office of River Protection, March 16), CH2M Hill Hanford Group, Inc., Richland, Washington.

EPA, 1996, Test Methods for Evaluating Solid Waste, Physical/Chemical Methods, SW-846, U.S. Environmental Protection Agency, Office of Solid Waste and Emergency Response, Washington, D.C.

FDH, 1998, Hanford Site Solid Waste Acceptance Criteria, HNF-EP-0063, Rev. 5, Fluor Daniel Hanford Inc., Richland, Washington.

Kirkbride, R. A., 1999, Tank Waste Remediation System Operation and Utilization Plan, HNF-SD-WM-SP-012, Revision 1, Vol. I and II, Numatec Hanford Corporation, Richland, Washington.

McCarthy, T. L., 1996, Hanford Site Radioactive Hazardous Material Packaging Directory, WHC-EP-0893, Westinghouse Hanford Company, Richland, Washington.

PNNL, 2000, Vapor Hydration Test Procedure, GDL-VHT, Technical Procedure No. GDL-VHT, Rev. 1, Pacific Northwest National Laboratory, Richland, Washington.

RL, 1996, TWRS Privatization Contract No. DE-RP06-96RL13308, Amendment A006, Contract with British Nuclear Fuels Ltd., U.S. Department of Energy, Richland Operations Office, Richland, Washington.

Smith, R. J., 1995, Packaging and Transportation of Radioactive Liquid at the U.S. Department of Energy Hanford Site, WHC-SA-2491-FP, Westinghouse Hanford Company, Richland, Washington. 
RPP-6227

Revision 0

APPENDIX A

SAMPLE SOURCE TERM

The following presents source terms for both the immobilized low-activity waste (ILAW) and immobilized high-level waste (IHLW) samples. Also included in this Appendix is a comparison of the sample source terms to the U.S. Department of Transportation (DOT) Type A limits.

\section{IMMOBILIZED LOW-ACTIVITY WASTE}

The Privatization Contract (RL 1996), Specification 2, contains bounding constraints for the ${ }^{90} \mathrm{Sr},{ }^{99} \mathrm{Tc}$, and ${ }^{137} \mathrm{Cs}$ content in ILAW. In addition, Specification 7 provides upper-bound values for the low-activity waste concentration of ${ }^{60} \mathrm{Co}$, ${ }^{154 / 155} \mathrm{Eu}$, and transuranics. By assuming contractual-imposed minimum sodium waste loading, the feed values can be transformed into its corresponding ILAW content. The resultant ILAW source term is presented in Table A-1.

Table A-1. ILAW Maximum Radionuclide Composition.

\begin{tabular}{|c|c|c|c|}
\hline Radionuclide & $\begin{array}{c}\text { Envelope A } \\
\left(\mathbf{C i} / \mathbf{m}^{3}\right)\end{array}$ & $\begin{array}{c}\text { Envelope B } \\
\left(\mathbf{C i} / \mathbf{m}^{3}\right)\end{array}$ & $\begin{array}{c}\text { Envelope C } \\
\left(\mathbf{C i} / \mathbf{m}^{3}\right)\end{array}$ \\
\hline${ }^{60} \mathrm{Co}$ & $3.03 \mathrm{E}-02$ & $1.14 \mathrm{E}-02$ & $1.61 \mathrm{E}-01$ \\
\hline${ }^{90} \mathrm{Sr}$ & $2.00 \mathrm{E}+01$ & $2.00 \mathrm{E}+01$ & $2.00 \mathrm{E}+01$ \\
\hline${ }^{99} \mathrm{Tc}$ & $1.00 \mathrm{E}-01$ & $1.00 \mathrm{E}-01$ & $1.00 \mathrm{E}-01$ \\
\hline${ }^{137} \mathrm{Cs}$ & $3.00 \mathrm{E}+00$ & $3.00 \mathrm{E}+00$ & $3.00 \mathrm{E}+00$ \\
\hline${ }^{154+155} \mathrm{Eu}$ & $5.96 \mathrm{E}-01$ & $2.23 \mathrm{E}-01$ & $1.87 \mathrm{E}+00$ \\
\hline Transuranics & $2.38 \mathrm{E}-01$ & $8.93 \mathrm{E}-02$ & $1.30 \mathrm{E}+00$ \\
\hline
\end{tabular}

As depicted in Table A-2, a 100-g ILAW sample from Envelope $\mathrm{C}$ (worst case) is well below the DOT Type A limit as defined in 49 CFR 173 (i.e., $\sum$ Ratio < 1). This analysis is very conservative because it is based on all radionuclides being simultaneously at their respective maximum. 
RPP-6227

Revision 0

Table A-2. ILAW Sample Activity versus Type A Package Limits.

\begin{tabular}{|c|c|c|c|}
\hline & Sample Activity & Activity Limit & Ratio \\
\hline Isotope & $\begin{array}{c}\mathrm{B}(\mathrm{i}) \\
(\mathrm{Ci})\end{array}$ & $\begin{array}{c}\mathrm{A}_{2}(\mathrm{i}) \\
(\mathrm{Ci})\end{array}$ & $\mathrm{B}(\mathrm{i}) / \mathrm{A}_{2}(\mathrm{i})$ \\
\hline${ }^{60} \mathrm{Co}$ & $6.10 \mathrm{E}-06$ & $1.08 \mathrm{E}+01$ & 0.00 \\
\hline${ }^{90} \mathrm{Sr}$ & $7.58 \mathrm{E}-04$ & $2.70 \mathrm{E}+00$ & 0.00 \\
\hline${ }^{99} \mathrm{Tc}$ & $3.79 \mathrm{E}-06$ & $2.43 \mathrm{E}+01$ & 0.00 \\
\hline${ }^{137} \mathrm{Cs}$ & $1.14 \mathrm{E}-04$ & $1.35 \mathrm{E}+01$ & 0.00 \\
\hline${ }^{241} \mathrm{Am}$ & $4.92 \mathrm{E}-05$ & $5.41 \mathrm{E}-03$ & 0.01 \\
\hline \multicolumn{3}{|c|}{ Total Sum } & 0.01 \\
\hline
\end{tabular}

\section{IMMOBILIZED HIGH-LEVEL WASTE}

The Privatization Contract (RL 1996), Specification 8, high-level waste envelope definition can be transformed into a source term by assuming a $50 \mathrm{wt} \%$ waste oxide loading. The resultant IHLW source term is as presented in Table A-3. In addition, the ${ }^{137} \mathrm{Cs}$ content of the IHLW has been adjusted to a value that would yield a $1,500 \mathrm{~W}$ canister without any contribution from other radionuclides.

Table A-3. IHLW Maximum Radionuclide Composition.

\begin{tabular}{|c|c|c|c|c|c|}
\hline Isotope & Ci/kg & Isotope & Ci/kg & Isotope & Ci/kg \\
\hline${ }^{3} \mathrm{H}$ & - & ${ }^{129} \mathrm{I}$ & $1.4 \mathrm{E}-06$ & ${ }^{237} \mathrm{~Np}$ & $3.7 \mathrm{E}-04$ \\
\hline${ }^{14} \mathrm{C}$ & - & ${ }^{137} \mathrm{Cs}$ & $9.9 \mathrm{E}+01$ & ${ }^{238} \mathrm{Pu}$ & $1.8 \mathrm{E}-03$ \\
\hline${ }^{60} \mathrm{Co}$ & $5.0 \mathrm{E}-02$ & ${ }^{152} \mathrm{Eu}$ & $2.4 \mathrm{E}-03$ & ${ }^{239} \mathrm{Pu}$ & $1.6 \mathrm{E}-02$ \\
\hline${ }^{90} \mathrm{Sr}$ & $5.0 \mathrm{E}+01$ & ${ }^{154} \mathrm{Eu}$ & $2.6 \mathrm{E}-01$ & ${ }^{241} \mathrm{Pu}$ & $1.1 \mathrm{E}-01$ \\
\hline${ }^{99} \mathrm{Tc}$ & $7.5 \mathrm{E}-02$ & ${ }^{155} \mathrm{Eu}$ & $1.5 \mathrm{E}-01$ & ${ }^{241} \mathrm{Am}$ & $4.5 \mathrm{E}-01$ \\
\hline${ }^{125} \mathrm{Sb}$ & $1.6 \mathrm{E}-01$ & ${ }^{233} \mathrm{U}$ & $4.5 \mathrm{E}-06$ & ${ }^{243+244} \mathrm{Cm}$ & $1.5 \mathrm{E}-02$ \\
\hline${ }^{126} \mathrm{Sn}$ & $7.4 \mathrm{E}-04$ & ${ }^{235} \mathrm{U}$ & $1.3 \mathrm{E}-06$ & & \\
\hline
\end{tabular}

- Some decay products (e.g." "Y from "Sr) and trace isotopes are not thown.

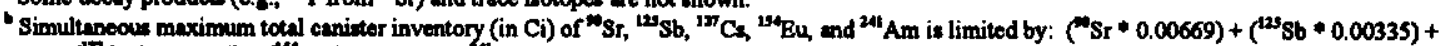
$\left({ }^{35} \mathrm{C} z * 0.00494\right)+\left({ }^{35} \mathrm{Bu} * 0.00898\right)+\left({ }^{3 m} \mathrm{Am} * 0.0328\right)<1,500$

As depicted in Table A-4, a 40-g IHLW sample with the maximum radionuclide content would exceed the DOT Type A limit as defined in 49 CFR 173 (i.e., $\Sigma$ Ratio $>1$ ). This analysis is, however, very conservative because it is based on all radionuclides being simultaneously at their respective maximum. Using a more likely glass composition, such as that predicted by the System Operation and Utilization Plan (SOUP) (Kirkbride 1999), the radionuclide content would be within the DOT Type A limit (i.e., the ratio summation is less than unity). This analysis is useful insofar as it indicates 
RPP-6227

Revision 0

that the IHLW product sample potentially could exceed the DOT Type A limit, particularly if the ${ }^{241} \mathrm{Am}$ content is near the maximum.

Table A-4. IHLW Sample Activity versus Type A Package Limits.

\begin{tabular}{|c|c|c|c|}
\hline & Sample Activity & Activity Limit & Ratio \\
\hline${ }^{\text {Isotope }}$ & $\begin{array}{c}\text { B(i) } \\
(\mathrm{Ci})\end{array}$ & $\begin{array}{c}\mathrm{A}_{2}(\mathrm{i}) \\
(\mathrm{Ci})\end{array}$ & B(i)/A $\mathrm{A}_{2}(\mathrm{i})$ \\
\hline${ }^{3} \mathrm{H}$ & -- & -- & - \\
\hline${ }^{14} \mathrm{C}$ & -- & -- & - \\
\hline${ }^{60} \mathrm{Co}$ & $2.00 \mathrm{E}-03$ & $1.08 \mathrm{E}+01$ & 0.00 \\
\hline${ }^{90} \mathrm{Sr}$ & $2.00 \mathrm{E}+00$ & $2.70 \mathrm{E}+00$ & 0.74 \\
\hline${ }^{99} \mathrm{Tc}$ & $3.00 \mathrm{E}-03$ & $2.43 \mathrm{E}+01$ & 0.00 \\
\hline${ }^{126} \mathrm{Sn}$ & $2.96 \mathrm{E}-05$ & $8.11 \mathrm{E}+00$ & 0.00 \\
\hline${ }^{125} \mathrm{Sb}$ & $6.40 \mathrm{E}-03$ & $2.43 \mathrm{E}+01$ & 0.00 \\
\hline${ }^{129} \mathrm{I}$ & $5.60 \mathrm{E}-08$ & Unlimited & \\
\hline${ }^{137} \mathrm{Cs}$ & $3.96 \mathrm{E}+00$ & $1.35 \mathrm{E}+01$ & 0.29 \\
\hline${ }^{152} \mathrm{Eu}$ & $9.60 \mathrm{E}-05$ & $2.43 \mathrm{E}+01$ & 0.00 \\
\hline${ }^{154} \mathrm{Eu}$ & $1.04 \mathrm{E}-02$ & $1.35 \mathrm{E}+01$ & 0.00 \\
\hline${ }^{155} \mathrm{Eu}$ & $6.00 \mathrm{E}-03$ & $5.41 \mathrm{E}+01$ & 0.00 \\
\hline${ }^{233} \mathrm{U}$ & $1.80 \mathrm{E}-02$ & $2.70 \mathrm{E}-02$ & 0.67 \\
\hline${ }^{235} \mathrm{U}$ & $5.20 \mathrm{E}-08$ & Unlimited & \\
\hline${ }^{237} \mathrm{~Np}$ & $1.48 \mathrm{E}-05$ & $5.41 \mathrm{E}-03$ & 0.00 \\
\hline${ }^{238} \mathrm{Pu}$ & $7.20 \mathrm{E}-05$ & $5.41 \mathrm{E}-03$ & 0.01 \\
\hline${ }^{239} \mathrm{Pu}$ & $6.40 \mathrm{E}-04$ & $5.41 \mathrm{E}-03$ & 0.12 \\
\hline${ }^{241} \mathrm{Pu}$ & $4.40 \mathrm{E}-03$ & $2.70 \mathrm{E}-01$ & 0.02 \\
\hline${ }^{241} \mathrm{Am}$ & $1.80 \mathrm{E}-02$ & $5.41 \mathrm{E}-03$ & 3.33 \\
\hline${ }^{244} \mathrm{Cm}$ & $6.00 \mathrm{E}-04$ & $1.08 \mathrm{E}-02$ & 0.06 \\
\hline & & Total Sum & 5.24 \\
\hline
\end{tabular}

\section{REFERENCES}

49 CFR 173 Subpart I, 1998, "Class 7 (Radioactive) Materials," Code of Federal Regulations, as amended.

Kirkbride, R. A., 1999, Tank Waste Remediation System Operation and Utilization Plan, HNF-SD-WM-SP-012, Revision 1, Vol. I and II, Numatec Hanford Corporation, Richland, Washington. 


\section{RPP-6227 \\ Revision 0}

RL, 1996, TWRS Privatization Contract No. DE-RP06-96RL13308, Amendment A006, Contract with British Nuclear Fuels Ltd., U.S. Department of Energy, Richland Operations Office, Richland, Washington. 
RPP-6227

Revision 0

\section{APPENDIX B \\ SAMPLE TRANSPORTATION PACKAGES}

The following presents a brief description of the proposed sample transportation packages. Additional details of these packages can be obtained from the Hanford Site Radioactive Hazardous Materials Packaging Directory (McCarthy 1996).

\section{HEDGEHOG}

The Hedgehog is a multi-configuration, shielded, U.S. Department of Transportation (DOT) Type A packaging (as defined in 49 CFR 173) for radioactive solids and liquids. Maximum weight for the complete package is roughly $29 \mathrm{~kg}$. The overall dimensions are about $48 \mathrm{~cm}$ square by $64 \mathrm{~cm}$ tall.

As depicted in Figure B-1, the overpack case consists of a polyethylene shell filled with a foam load spacer. In its basic configuration (no shielding), the payload is enclosed within a 1-L polyethylene container. Additional configurations are possible that include a stainless steel inner container for shielding. This shielding, however, reduces the payload volume. Figure B-2 presents the 250-ml payload configuration.

\section{POST-ACCIDENT SAMPLE-1}

The Post-Accident Sample-1 (PAS-1) cask is a heavily shielded, DOT Type B packaging (as defined in 49 CFR 173 and 10 CFR 71). The maximum loaded weight of the PAS-1 cask is $5,800 \mathrm{~kg}$. The overall dimensions are about $122 \mathrm{~cm}$ in diameter and $168 \mathrm{~cm}$ tall.

As shown in Figure B-3 the PAS-1 cask consists of two containment barriers. The primary (inner) containment vessel is stainless steel while the secondary containment vessel is lead clad in carbon steel. The secondary containment vessel provides the bulk of biological shielding necessary to meet transportation requirements. Impact protection is provided by two foam-filled, steel-clad overpacks. The tiedown assembly for the PAS-1 cask consists of a floor pallet, three turnbuckles, an overhead fixture, three tiedown points, and three anchor points.

Past practice at the Hanford Site is to further contain the payload within a sample carrier (see Figure B-4). The sample carrier provides some shielding during transport, but its primary function is to provide shielding when the cask is opened in a controlled environment. 


\section{RPP-6227}

Revision 0

\section{REFERENCES}

McCarthy, T. L., 1996, Hanford Site Radioactive Hazardous Material Packaging Directory, WHC-EP-0893, Westinghouse Hanford Company, Richland, Washington. 
RPP-6227

Revision 0

Figure B-1. Hedgehog.

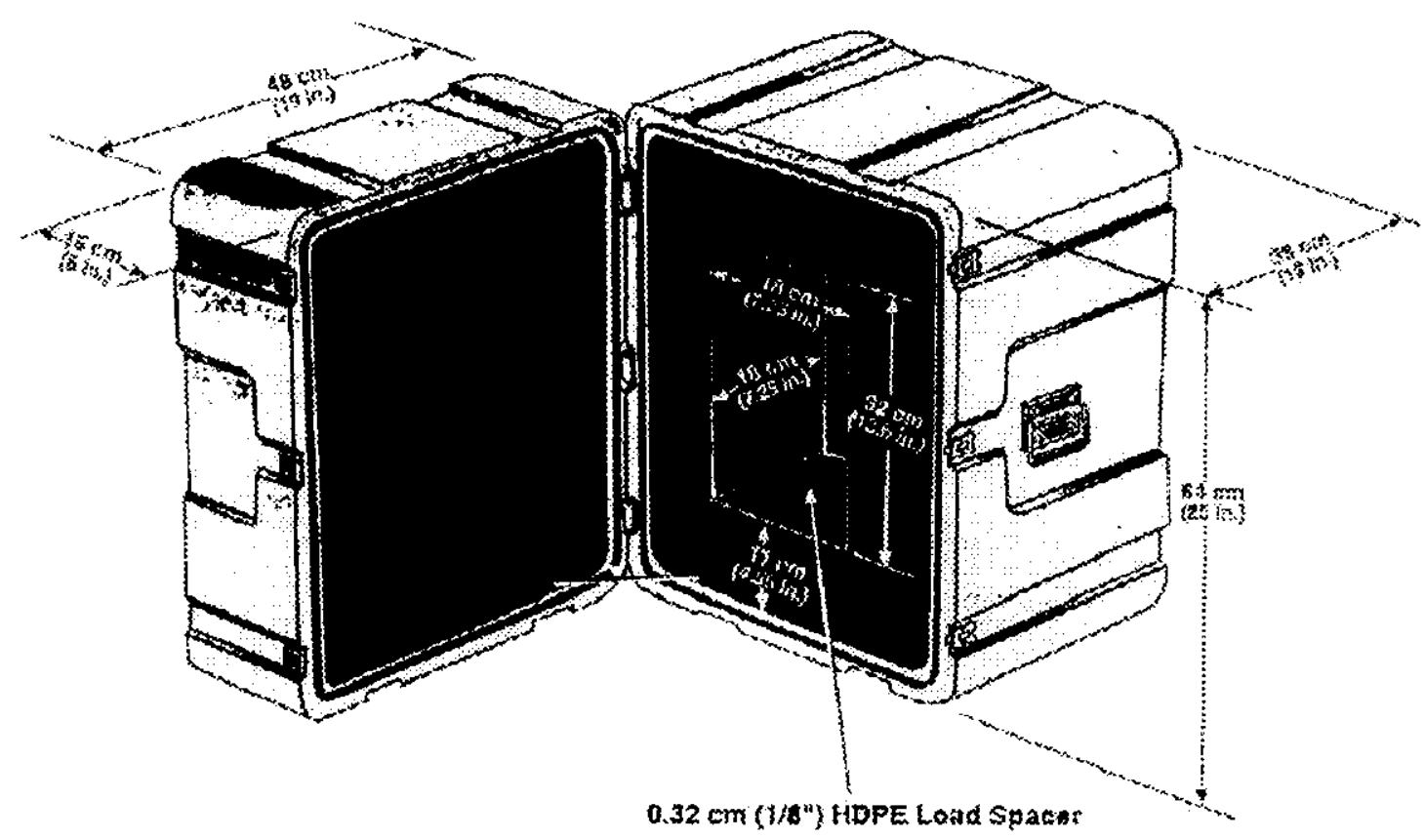

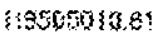




\section{RPP-6227}

Revision 0

Figure B-2. $250 \mathrm{ml}$ Sample Container.

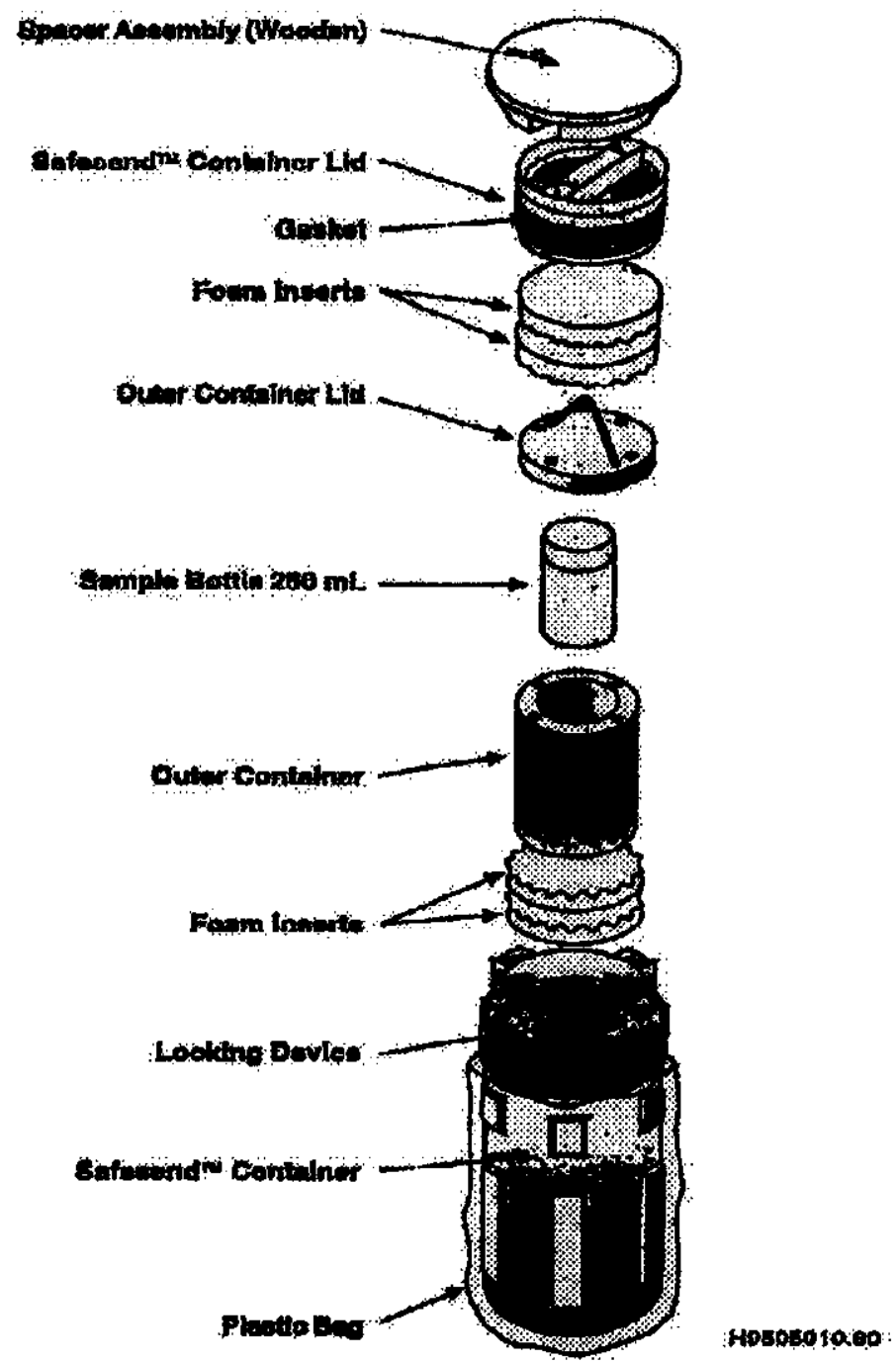


RPP-6227

Revision 0

Figure B-3. Post-Accident Sample-1 Cask.

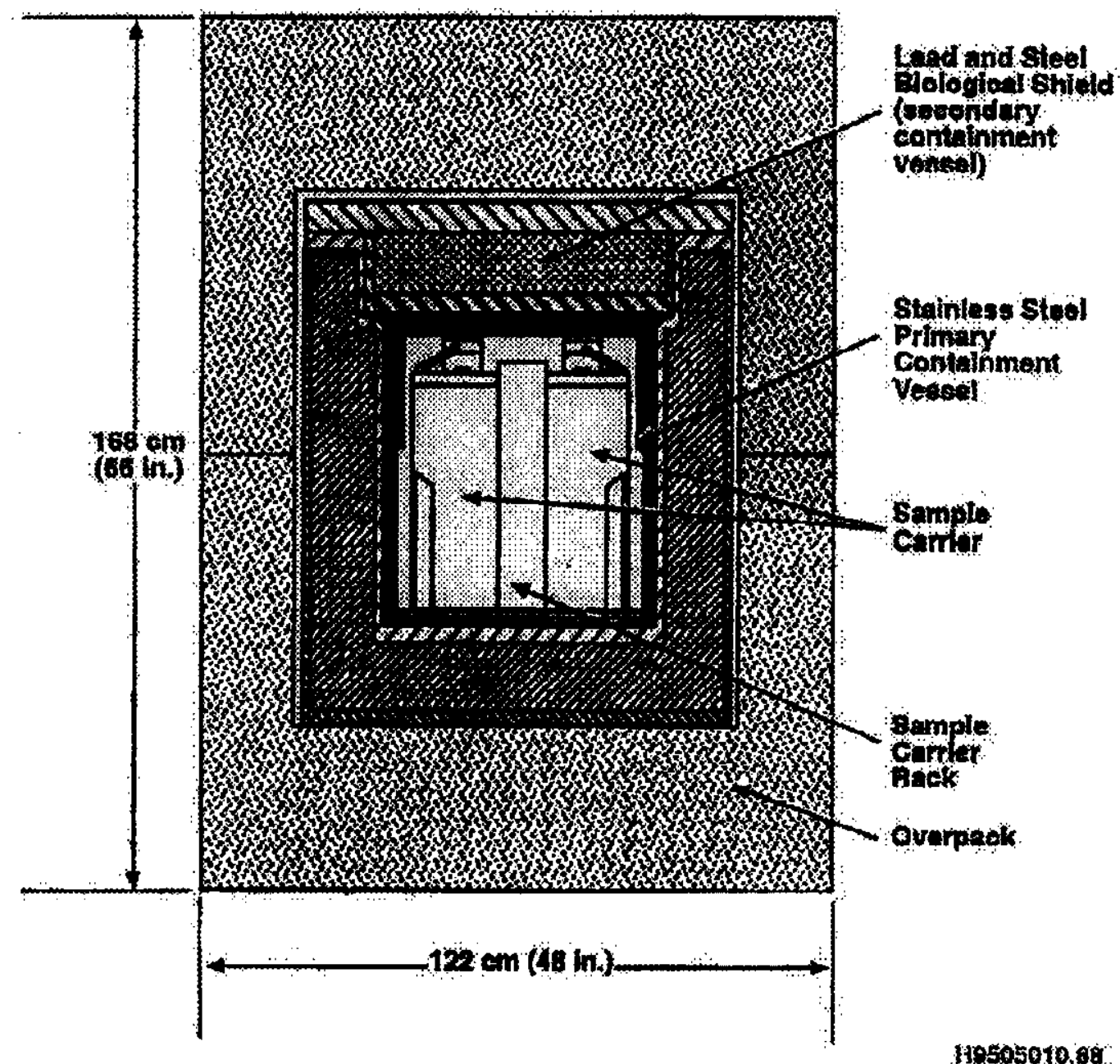




\section{RPP-6227 \\ Revision 0}

Figure B-4. Shielded Sample Container.

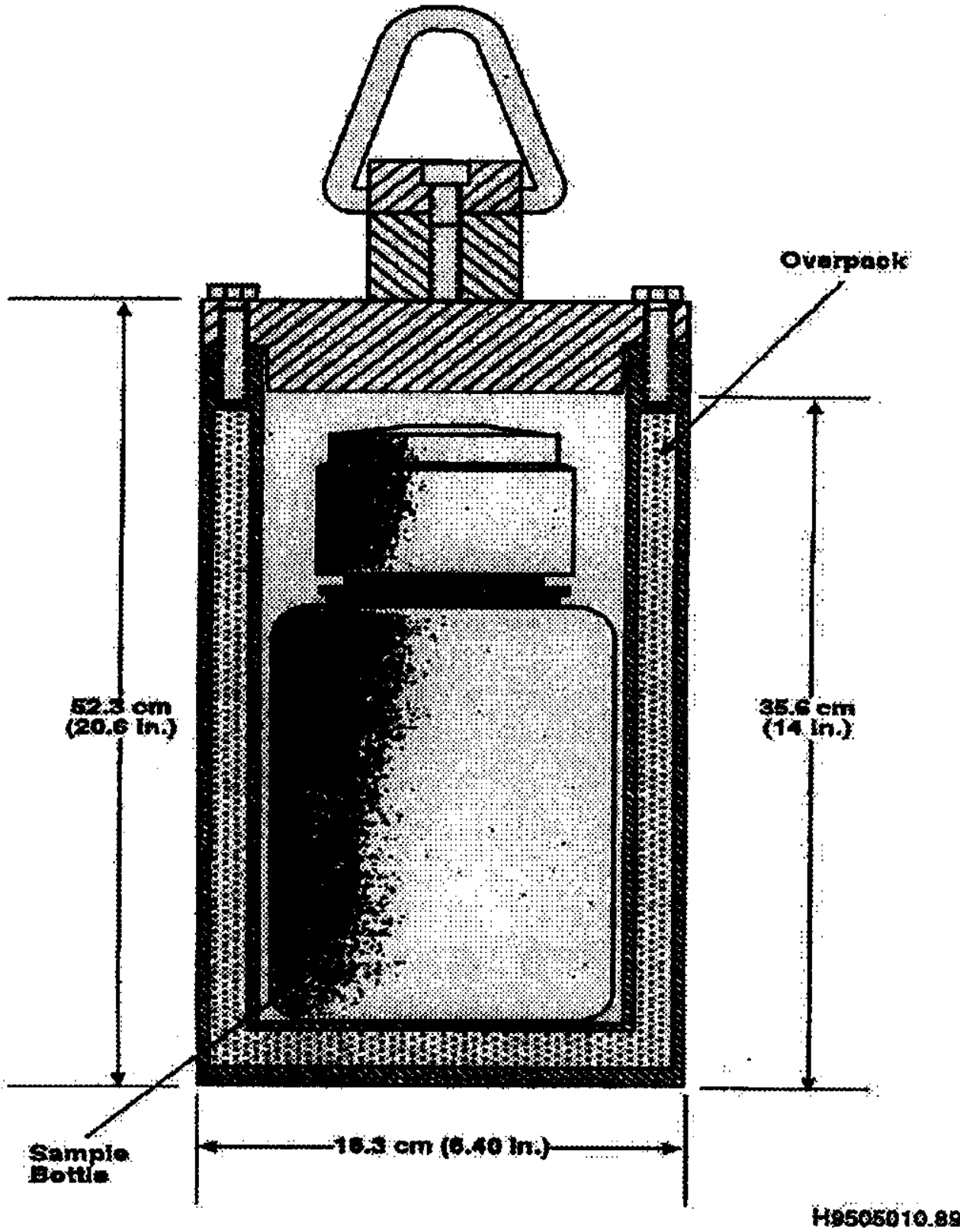

